\title{
PROPERTIES OF LACTATE DEHYDROGENASE CRYSTALS REACTED WITH DIIMIDOESTERS
}

\author{
by \\ STEPHEN BAYNE \\ and \\ MARTIN OTTESEN \\ Department of Chemistry, Carlsberg Laboratory \\ Gamle Carlsberg Vej 10, DK-2500 Copenhagen, Valby
}

Keywords: lactate dehydrogenase crystals, diimidoesters, activity, lysine modification, kinetics

Pig heart lactate dehydrogenase crystals were reacted under mild conditions in saturated sodium sulphate solution with a homologous series of diimidoesters varying in chain length from five to twelve carbon atoms. With diimidoesters of chain length of eight or nine carbon atoms the crystals were stabilized, with less than seven carbon atoms, the reacted crystals dissolved, whereas with diimidoesters of ten to twelve carbon atoms, mixtures of amorphous insoluble material and crystals resulted. The physical appearance of the enzyme was correlated with both its specific activity and degree of lysine modification. The MichaELIS parameters were determined for crystals reacted with hexane- and octanediimidic acid dimethylesters and the values compared with those for unmodified lactate dehydrogenase. The $K_{m}$ values for reduced coenzyme were increased in the cross-linked enzyme while the $K_{m}$ values for pyruvate remained virtually unchanged. $V_{\max }$ values were only affected to a minor extent for these two derivatives. The correlation between the "static " mechanism proposed by $\mathrm{X}$-ray analysis and the reaction mechanism in dilute solution is discussed.

\section{INTRODUCTION}

Recent reports concerning the properties of crystalline enzymes have compared the kinetic parameters of cross-linked insoluble crystals with those of the corresponding soluble enzymes $(11,15,18)$. In some cases, crystallization decreases $k_{c a t}$ with small changes of $K_{m}$; in others, only small changes in both $\mathrm{k}_{\text {cat }}$ and $\mathrm{K}_{\mathrm{m}}$ have been noted.
Not all enzymes can withstand glutaraldehyde treatment. Cross-linking of pig heart lactate dehydrogenase (LDH) crystals with this reagent produced amorphous, insoluble structures of low activity. However, as described in a previous report from this laboratory, insoluble LDH crystals can be prepared by reaction with octanediimidic acid dimethylester $\left(\mathrm{C}_{8}\right)(1)$. 
Table I

Melting point ranges and elemental analyses of diimidoesters prepared as described in section $\mathbf{2 . 2}$.

\begin{tabular}{|c|c|c|c|c|c|c|c|}
\hline \multirow[b]{3}{*}{ Diimidoester } & \multirow[b]{3}{*}{ m.p.range $\left({ }^{\circ} \mathrm{C}\right)$} & \multicolumn{6}{|c|}{ Elemental analyses } \\
\hline & & \multicolumn{3}{|c|}{ Expected } & \multicolumn{3}{|c|}{ Found } \\
\hline & & C & $\mathrm{H}$ & $\mathrm{N}$ & C & $\mathrm{H}$ & $\mathrm{N}$ \\
\hline $\mathrm{C}_{5}$ & $118-120$ & 36.4 & 6.9 & 12.1 & 35.5 & 6.9 & 12.3 \\
\hline $\mathrm{C}$ & $\begin{array}{l}125-128 \\
(175-175.5(8))\end{array}$ & 41.7 & 7.7 & 10.8 & 41.1 & 7.9 & 10.6 \\
\hline $\mathrm{C}_{8}$ & $\begin{array}{l}215-217 \\
(214-15(7))\end{array}$ & 43.9 & 8.1 & 10.3 & 43.9 & 8.2 & 10.4 \\
\hline $\mathrm{C}_{9}$ & $110-112$ & 46.0 & 8.4 & 9.8 & 45.9 & 8.6 & 9.9 \\
\hline $\mathrm{C}_{10}$ & $202-204$ & 47.8 & 8.6 & 9.3 & 47.7 & 8.7 & 9.4 \\
\hline $\mathrm{C}_{11}$ & $108-111$ & 49.5 & 8.9 & 8.9 & 47.7 & 9.0 & 9.8 \\
\hline$C_{12}$ & $184-186$ & 51.1 & 9.1 & 8.5 & 50.9 & 9.4 & 8.5 \\
\hline
\end{tabular}

In the present paper, this work has been extended to include other diimidoesters ranging in chain length from five carbon atoms to twelve carbon atoms $\left(\mathrm{C}_{5}-\mathrm{C}_{12}\right)$ and it was demonstrated that the solubility state of the reacted crystals depended on the diimidoester chain length and to a lesser extent, on the diimidoester concentration.

The MichaElis parameters for $\beta$-nicotinamide-adenine dinucleotide (reduced) (NADH) and sodium pyruvate of $\mathrm{LDH}$ crystals reacted with $\mathrm{C}_{6}$ - and $\mathrm{C}_{8}$-diimidoesters were determined and compared with the results obtained for unmodified $\mathrm{LDH}$. The $\mathrm{C}_{6}$-reacted crystals went into solution, while $\mathrm{C}_{8}$-reacted crystals were insoluble making it possible to compare the effect of the solubility state on the MichaELIS parameters.

\section{EXPERIMENTAL}

\subsection{Enzyme and coenzyme}

Crystalline LDH was prepared from pig hearts by the method of REEvEs and FumOGNARI (14) with minor modifications. The

\footnotetext{
Abbreviations used: $\mathrm{LDH}=$ pig heart lactate dehydrogenase; $\mathrm{NADH}=\beta$-nicotinamideadenine dinucleotide, reduced; $C_{5}, C_{6}, C_{7}, C_{8}, C_{9}, C_{10}, C_{11}$ and $C_{12}$ correspond to pentane-, hexane-, heptane-, octane-, nonane-, decane-, undecane- and dodecanediimidic acid dimethylester, respectively.
}

enzyme was stored as crystals in $55 \%$ saturated ammonium sulphate, $\mathrm{pH} 6.3$. The amino, acid composition agreed with the values previously reported (1). The enzyme had a specific activity of $400 \mathrm{U} / \mathrm{mg}$ at $25^{\circ} \mathrm{C}$.

NADH disodium salt (batch no. 227512A), a commercial product of Carlsberg Breweries, Copenhagen, was used for activity measurements. For kinetic studies, NADH disodium salt was prepared from the NADH barium salt (Carlsberg batch no. 107702) and was used within $12 \mathrm{~h}$ of preparation. This solution had an $\mathrm{E}_{260 \mathrm{~nm}} / \mathrm{E}_{340 \mathrm{~nm}}$ ratio of 2.35 .

\subsection{Chemicals}

$\mathrm{C}_{6}$ was obtained from Pierce (Rockford, 11linois). The remaining diimidoesters $\left(C_{5}-C_{12}\right)$ were synthesised from the corresponding dinitriles (Fluka) essentially as described by McElvaiN and SCHROEDER (13) for the preparation of butanediimidic acid dimethylester. Typically, $2 \mathrm{ml} \mathrm{1,5-dicyanopentane} \mathrm{was}$ mixed with $8.6 \mathrm{ml}$ dioxane and $2 \mathrm{ml}$ methanol. The solution was cooled to $0^{\circ} \mathrm{C}$ and $\mathrm{HCl}$ gas $(1.8 \mathrm{~g})$ was bubbled very slowly through the solution. After $48 \mathrm{~h}, 10 \mathrm{ml}$ diethylether was added and the crystalline suspension left for $1 \mathrm{~h}$ at $3^{\circ} \mathrm{C}$. The crystals were then filtered and washed with cold diethylether:methanol $(3: 1,100 \mathrm{ml})$ before being dried under vacuum. The resulting diimidoesters were characterised by elemental analyses and melting points (Table I). 
Dimethyl-3,3'-dithiobispropionimidate was obtained from Pierce. Methyl-3-mercaptopropionimidate was synthesised by the method of TrAUT et al. (17). Redistilled 3-chloropropionitrile (Merck, 33,2 g) was added to $38 \mathrm{~g}$ thiourea and $25.2 \mathrm{ml}$ water. After refluxing $\left(120^{\circ} \mathrm{C}, 2 \mathrm{~h}\right)$ and cooling to room temperature, $500 \mathrm{ml}$ cold acetone was added. The crystalline sait, 3-isothioureido-propionitrile, which precipitated immediately, was filtered after 15 min at $4^{\circ} \mathrm{C}$, washed with $3 \times 50 \mathrm{ml}$ cold acetone and $2 \times 50 \mathrm{ml}$ diethylether, then finally air-dried overnight (yield $56 \mathrm{~g}(80 \%)$, m.p. range 158$162^{\circ} \mathrm{C}$ ).

The 3-isothioureidopropionitrile ( $23 \mathrm{~g}$ ) was dissolved in $30 \mathrm{ml}$ degassed water and warmed to $50^{\circ} \mathrm{C}$. $\mathrm{NaOH}$ solution $(14.0 \mathrm{ml}, 50 \%(\mathrm{w} / \mathrm{v}))$ was added with stirring under nitrogen and stirring continued for $30 \mathrm{~min}$. From this mixture, 3-mercaptopropionitrile was extracted by ether as described by Traut et al. (17). The yellow oil obtained (yield $6.3 \mathrm{~g}(52 \%)$ ) was distilled under vacuum and a colourless oil collected (b.p. range $39-40^{\circ} \mathrm{C}, 260 \mathrm{~Pa}$ ).

To $4.0 \mathrm{ml}$ cold methanol was added $\mathrm{HCl}$ gas $(3.2 \mathrm{~g})$, followed quickly by $2.5 \mathrm{~g} 3$-mercaptopropionitrile. The flask was tightly stoppered and left overnight at $3^{\circ} \mathrm{C}$. Diethylether $(25 \mathrm{ml})$ was added to the solution and after standing for $1 \mathrm{~h}$ at $3^{\circ} \mathrm{C}$, the crystals were washed with $20 \mathrm{ml}$ diethylether: methanol (3:1). Methyl-3-mercaptopropionitrile (yield 2.6 $\mathrm{g}(60 \%)$, m.p. range $\left.83-84^{\circ} \mathrm{C}\right)$ was obtained.

\subsection{Reaction of $L D H$ crystals with diimidoesters}

LDH crystals suspended in saturated sodium sulphate were reacted with a homologous series of diimidoesters essentially as described previously for the $\mathrm{C}_{8}$-diimidoester (1). Both diimidoesters with shorter chains $\left(\mathrm{C}_{5}, \mathrm{C}_{6}, \mathrm{C}_{7}\right)$ and longer chains $\left(C_{9}-C_{12}\right)$ than $C_{8}$ were employed.

Typically, LDH crystals $(7.5 \mathrm{mg})$ suspended in ammonium sulphate were centrifuged and washed twice with sodium sulphate solution. The crystals were suspended in saturated sodium sulphate $\left(7.5 \mathrm{ml}, 25^{\circ} \mathrm{C}\right)$ and divided into three equal aliquots. To each of the three aliquots was added the required diimidoester in the ratios $0.6,1.0$ and 2.0 mole per mole lysine residues, respectively. After $200 \mathrm{~min}$ reaction,

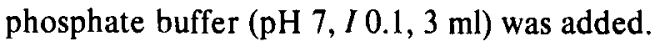
Crystals reacted with $\mathrm{C}_{5}$-and $\mathrm{C}_{6}$-diimidoesters dissolved immediately, irrespective of the diimidoester concentration. For crystals reacted with $\mathrm{C}_{7}-\mathrm{C}_{12}$-diimidoesters, increasing chain length and concentration of diimidoester resulted in less protein being dissolved during repeated washing with phosphate buffer. Where the crystals had reacted with a twomolar excess of diimidoesters of chain length greater than $\mathrm{C}_{\mathbf{B}}$, a single washing was sufficient to remove all soluble protein. Crystals reacted with a ratio of 0.6 mole diimidoester of chain length $C_{7}-C_{10}$ dissolved gradually on repeated washing. Crystals reacted with a ratio of 1.0 mole diimidoester were washed to a maximum of six times. This did not mean that all the soluble protein was released from the reacted crystals. Reacted crystals remaining after washing were suspended in phosphate buffer ( 3 $\mathrm{ml})$.

The kinetic studies (section 2.6) were performed with LDH crystals which had been reacted with $\mathrm{C}_{6}$-and $\mathrm{C}_{8}$-diimidoesters in a ratio of 1.2 mole per mole lysine residue.

\subsection{Activity measurements of soluble and diimi- doester-reacted LDH}

Activity was measured by recording the oxidation of NADH at $340 \mathrm{~nm}$ and was expressed as $\mu \mathrm{mol} \mathrm{NADH}$ oxidised per min per mg enzyme or enzyme crystals (units/mg). In the assay cuvette was pipetted phosphate buffer (3.0, pH $7, I 0.1), \mathrm{NADH}$ solution $(5 \mathrm{mg} / \mathrm{ml}, 100 \mu \mathrm{l})$ and sodium pyruvate solution $(2.5 \mathrm{mg} / \mathrm{ml}, 100 \mu \mathrm{l})$. The reaction was initiated by the addition of 5 $20 \mu \mathrm{l}$ of a suitably diluted aliquot of enzyme solution or enzyme crystal suspension.

\subsection{Amino acid analyses}

Amino acid analyses were carried out as described previously (1). The extent of lysine residue modification was determined by hydrolysing crystal samples for 24,48 and $96 \mathrm{~h}$ and subsequent extrapolation of the values for 
free lysine. The alanine content was used as a standard to calculate the amount of protein in the crystals.

\subsection{Kinetics studies}

All experiments were performed at $25^{\circ} \mathrm{C}$ in phosphate buffer ( $\mathrm{pH} 7, I 0.1)$. total volume was $3 \mathrm{ml}$. Initial rates were measured by recording the oxidation of NADH at $340 \mathrm{~nm}$. For use in kinetic studies, soluble LDH was treated with active charcoal (19) to remove bound nucleotide; $\mathrm{LDH}$ crystals were reacted with $\mathrm{C}_{6}{ }^{-}$ and $\mathrm{C}_{8}$-diimidoesters. The MichaELIS parameters were calculated from secondary replots of the primary reciprocal plots according to DALZIEL (5).

In one set of experiments for both the soluble enzyme and the chemically modified LDH crystals, the pyruvate concentration was varied from 15-120 $\mu \mathrm{M}$ with the NADH concentration held constant at $140 \mu \mathrm{M}, 14 \mu \mathrm{M}$ and $7 \mu \mathrm{M}$, respectively, for the soluble enzyme and at 196 $\mu \mathrm{M}, 77 \mu \mathrm{M}$ and $44 \mu \mathrm{M}$, respectively, for the reacted crystals. In another set of experiments the NADH concentration was varied from $3-42 \mu \mathrm{M}$ with the pyruvate held constant at $76 \mu \mathrm{M}, 53 \mu \mathrm{M}$ and $31 \mu \mathrm{M}$, respectively, for the soluble enzyme. For the chemically modified crystals NADH was varied from $20-150 \mu \mathrm{M}$ with pyruvate held constant at $760 \mu \mathrm{M}, 92 \mu \mathrm{M}$ and $38 \mu \mathrm{M}$, respectively. The reactions were initiated by the addition of soluble $\mathrm{LDH}(0.01 \mu \mathrm{g}$ in $2 \mu \mathrm{l})$ or reacted $\mathrm{LDH}$ crystals $\left(0.04 \mu \mathrm{g} \mathrm{C}_{6}\right.$-reacted or $0.08 \mu \mathrm{g} \mathrm{C}_{8}$-reacted $\mathrm{LDH}$, each in $3 \mu \mathrm{l}$ ).

\section{RESULTS}

\subsection{Effect of diimidoester chain length and con- centration on the properties of LDH crystals}

LDH crystals were reacted with a series of diimidoesters of different carbon chain length at different concentrations. The effects on the activity and solubility properties of the crystalline LDH are summarised in Fig. 1. As indicated in the figure, $\mathrm{LDH}$ crystals reacted with $\mathrm{C}_{5}$ - and $\mathrm{C}_{6}$-diimidoesters dissolved on dilution of the reaction medium with phosphate buffer, at all three concentrations of diimidoester. Likewise, $\mathrm{C}_{7}$-reacted crystals dissolved at the lowest concentration used (Fig. 1A); at the intermidiate $\mathrm{C}_{7}$-concentration (Fig. 1B), a slow dissolution was observed over $24 \mathrm{~h}$ in contrast to the instantaneous dissolution of the previous examples. Gel filtration on Sepharose 4 B of LDH which had dissolved after reaction with excess $\mathrm{C}_{6}$-diimidoester, showed a wide range of particle sizes, all of which showed LDH activity. The largest activity occurred at the elution position of the LDH tetramer but a relatively large fraction of the activity was also noted at the column exclusion volume.

The reaction between $\mathrm{LDH}$ crystals and $\mathrm{C}_{7}$ diimidoester was studied at a variety of diimidoester concentrations. Increasing the concentrations from 0.6 mole to 5.0 mole diimidoester per mole lysine residue changed the solubility properties of the reacted crystals from being completely soluble through crystalline to completely amorphous with corresponding decreases in activity.

The decrease of enzyme activity and solubility with increasing diimidoester chain length may be due to the hydrophobic effect caused by the increasing length of aliphatic chains or by the longer diimidoesters reacting with a lysine residue in the proximity of the active site. The longer aliphatic chain may prevent free access of the substrates to the binding sites.

The decrease of activity of LDH crystals after reaction with diimidoesters might be due to

Figure 1. Effect of the reaction of various diimidoesters on the activity (left ordinate), extent of lysine modification (right ordinate) and physical appearance of LDH crystals (block bars). Activity $(0-0)$ was determined as described in section 2.4. Extent of lysine modification $(\mathrm{I}-\mathrm{I})$ was calculated by extrapolation after hydrolysis of crystal samples as described in section 2.5. Fig. $1 \mathrm{~A}, 1 \mathrm{~B}$ and $1 \mathrm{C}$ were obtained after reacting $\mathrm{LDH}$ crystals with a ratio of 0.6 mole, 1.0 mole and 2.0 mole diimidoester per mole lysine residues, respectively, as described in section 2.3. The block bars above each Figure represent the physical appearance of the diimidoester treated LDH preparation, immediately before dilution in the assay medium: line; $\$$ 


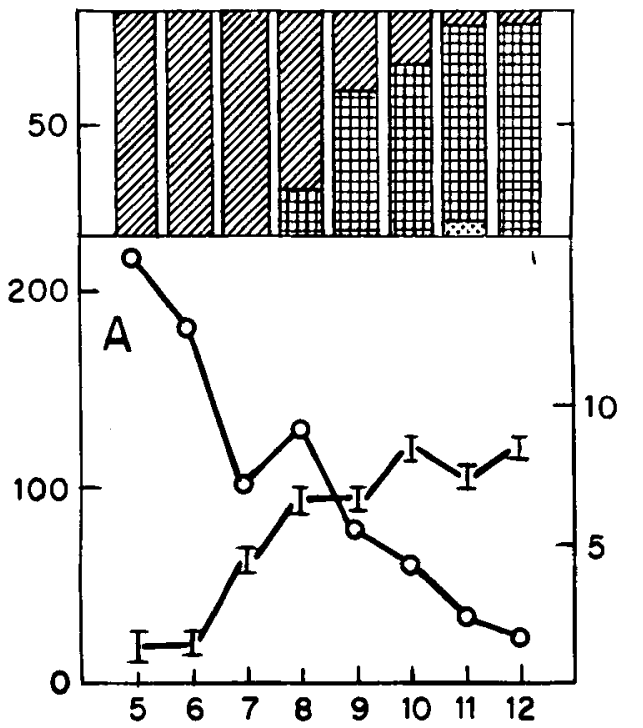

either an indirect effect of crystal structure restricting access of substrates to all the active sites or to a direct effect of the modification of lysine residues critical for substrate binding and catalysis. In an attempt to distinguish these two possibilities, $\mathrm{LDH}$ crystals and soluble $\mathrm{LDH}$ were both reacted with the monofunctional immidate reagent, methyl-3-mercaptopropionimidate, and with the bifunctional dimethyl-3,3'dithiobispropionimidate in a $1: 1$ molar ratio based on lysine under conditions described in section 2.6 for the reaction of diimidoesters with LDH crystals. Soluble LDH, which had reacted with both reagents, remained soluble and retained $90-100 \%$ activity of the unreacted enzyme. Methyl-3-mercaptopropionimidate reacted $\mathrm{LDH}$ crystals dissolved as expected on dilution with phosphate buffer with retention of $90-100 \%$ of their free enzyme activity. LDH crystals reacted with dimethyl-3,3'dithiobispropionimidate were insoluble and retained only $30 \%$ of the activity of the free enzyme. These results suggest that the decreased activities of the insoluble crystals are caused not by chemical modification of lysine residues but the crystal structure restricting access of substrates to the active sites. The possibility still exists, however, that more extensive lysine modifications might involve critical residues.

\subsection{Kinetic studies}

The kinetic parameters of $\mathrm{C}_{6}$-modified and $\mathrm{C}_{\mathbf{8}}$-modified crystals have been studied in detail and the results are presented in the following. As described in section $2.3, \mathrm{C}_{6}$-crystals were soluble whereas $\mathrm{C}_{8}$-crystals were insoluble; these two derivatives contained two and six modified lysine residues per subunit, respectively.

The reaction rates of the diimidoester reacted crystals were found to be independent of the protein concentration, when assayed under the conditions used for soluble enzyme as described in section 2.4.

The general equation for a two-substrate enzyme might be described according to LAIDLER and BUNTING (12) as

$$
v=\frac{v[A][B]}{K_{A} K_{B}+K_{B}[A]+K_{A}[B]+[A][B]}
$$


where $\mathrm{V}$ is the velocity; $\mathrm{V}$ is the limiting velocity; $[A],[B]$ are the concentrations of substrates $A$ and $B$, respectively; $K_{A}, K_{B}$ are the Michaelis constants for $A$ and $B$, respectively; $\mathrm{K}_{\mathrm{A}}$ ' is the dissociation constant of $A$ from the enzyme.

This equation is easily transformed, for use with double reciprocal plots of $1 / \mathrm{v}$ against $1 /[\mathrm{A}]$ and of $1 / v$ against $1 /[B]$, into

$$
1 / v=\left(1+\frac{K_{A}}{[A]}+\frac{K_{B}}{[B]}+\frac{K_{A}{ }^{\prime} K_{B}}{[A][B]}\right) / V
$$

The primary plots of $1 / \mathrm{v}$ against $1 /$ [A] (first substrate) at constant [B] (second substrate) will be linear, as will a primary plot of $1 / \mathrm{v}$ against $1 /[\mathrm{B}]$ at constant [A]. The correct kinetic parameters for one substrate at infinite concentrations of the other substrate can then be determined from replots of intercepts and slopes against the reciprocal concentation of the second substrate (secondary replots) (5).

Primary plots obtained for ummodified LDH with NADH and pyruvate as substrates are presented in Figs. 2A and 3A, respectively. As shown, the lines will meet at a point close to the abscissa. Slopes and intercepts of these plots were calculated from the data determined by the method described by CORNISH-BOWDEN (4). The calculated values were used in seceondary replots (5) (Figs. 4A, 4B, 5A and 5B) to determine the Michaelis parameters by linear regression (Table II).

The $K_{m}$ values for NADH and pyruvate(Table II) for unmodified LDH were in good agreement with those reported elsewhere $(2,3)$; the $\mathrm{V}_{\max }$ value was higher than that previously

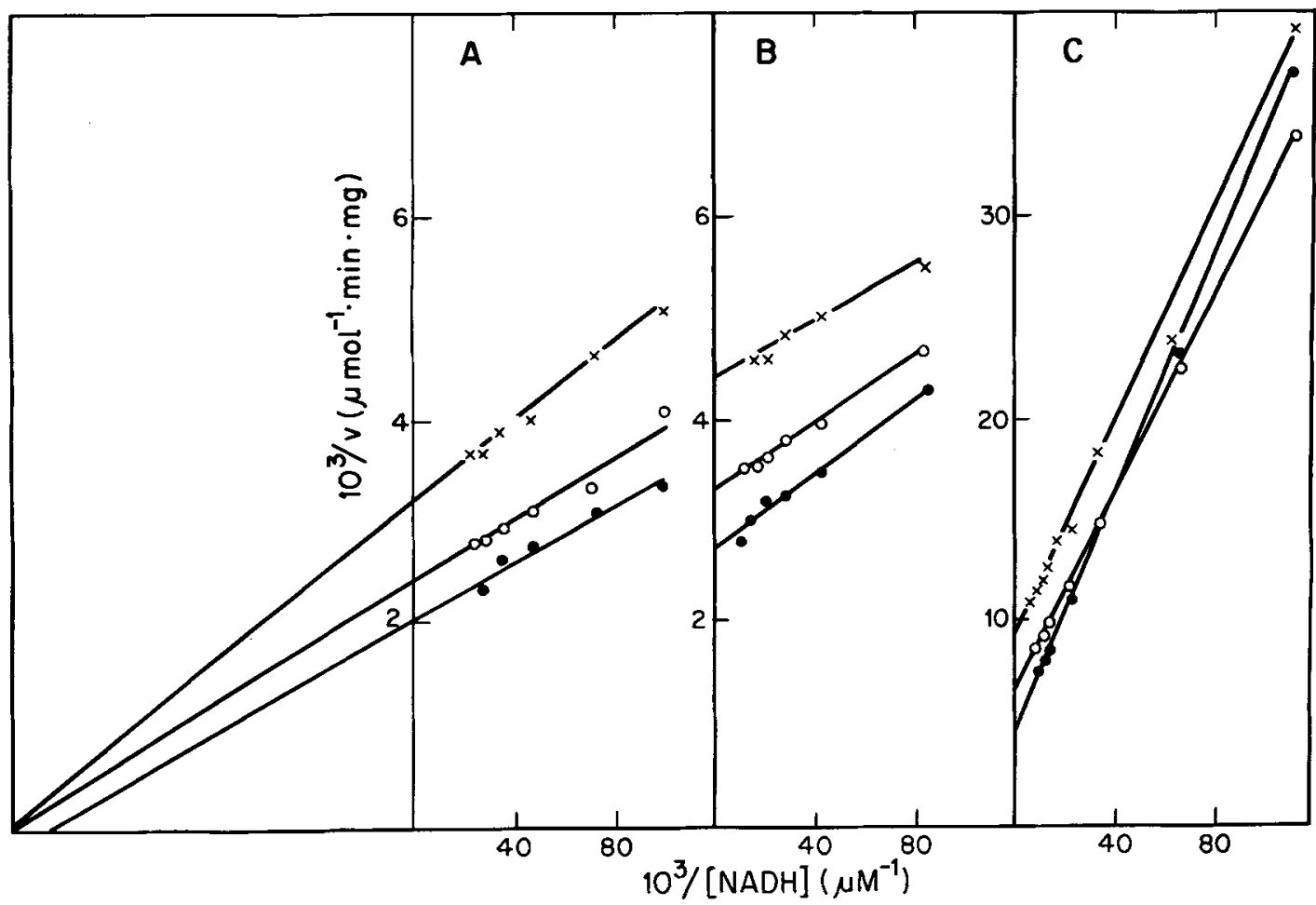

Figure 2. Steady-state rate of pyruvate reduction as a function of NADH concentration for unmodified $\mathrm{LDH}, \mathrm{C}_{6}$ modified and $\mathrm{C}_{8}$-modified LDH crystals. Initial velocities were obtained as described in section 2.6. The reciprocal steady-state rate is plotted against the reciprocal NADH concentration. The pyruvate concentration was held constant for each reciprocal plot. Fig. 2 A, unmodified LDH; Fig. 2 B, C 6 -modified LDH crystals; Fig. 2 $\mathrm{C}, \mathrm{C}_{8}$-modified LDH crystals. - - highest pyruvate concentration; $0-0$, intermediate concentration; $x-x$, lowest concentration (see section 2.6.). 


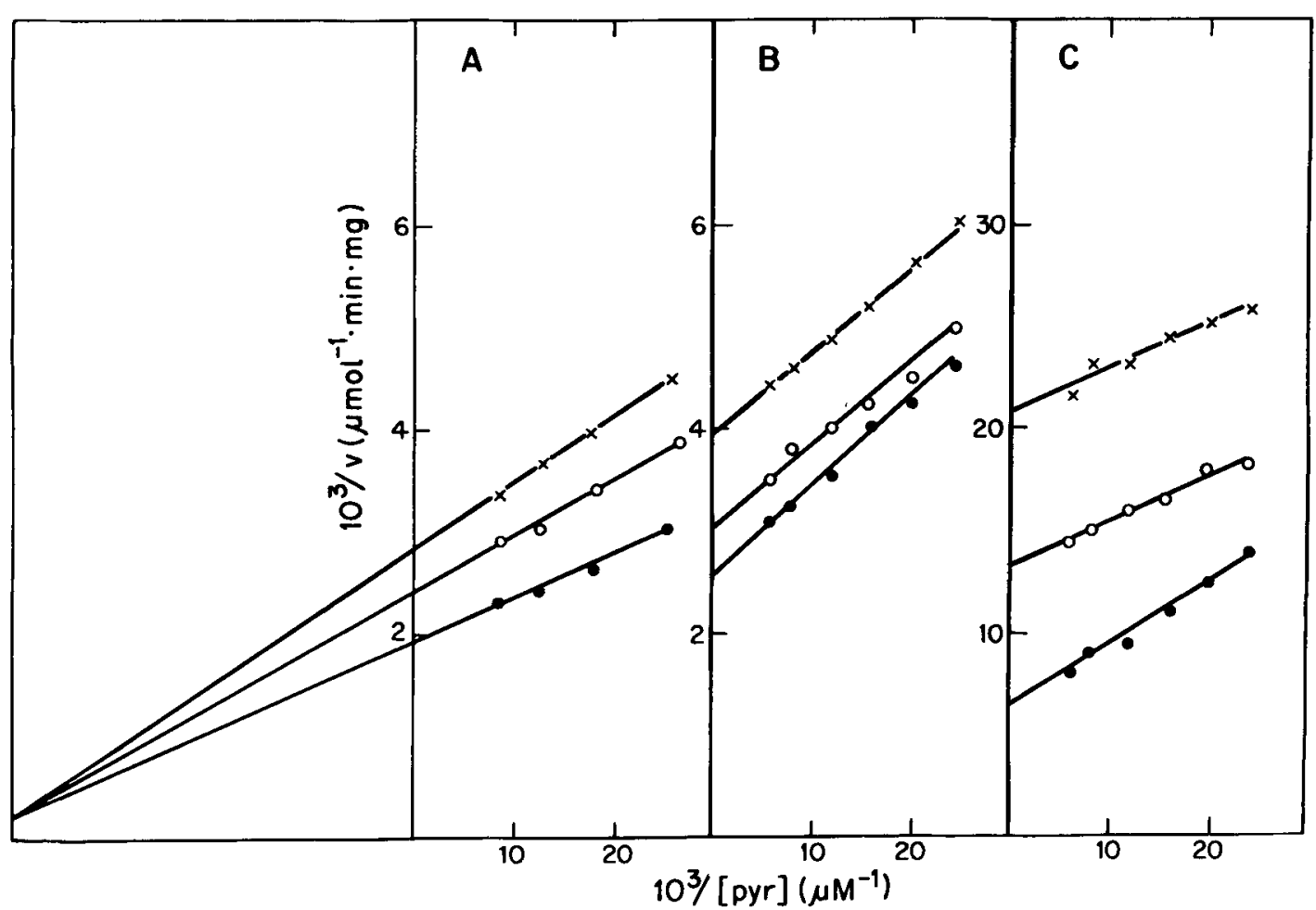

Figure 3. Steady-state rate of NADH oxidation as a function of pyruvate concentration for unmodified $\mathrm{LDH}, \mathrm{C}_{6}$ modified and $\mathrm{C}_{\mathrm{g}}$-modified $\mathrm{LDH}$ crystals. Initial velocities were obtained as described in section 2.6. The reciprocal steady-state rate is plotted against the reciprocal pyruvate concentration. The NADH concentration was held constant for each reciprocal plot. Fig. 3 A, unmodified LDH; Fig. 3 B, C 6 -modified LDH crystals, Fig. 3 $\mathrm{C}, \mathrm{C}_{\mathrm{B}}$-modified LDH-crystals; $-\bullet$, highest NADH concentration; $0-0$, intermediate NADH concentration; $x-x$, lowest NADH concentration (see section 2.6.).

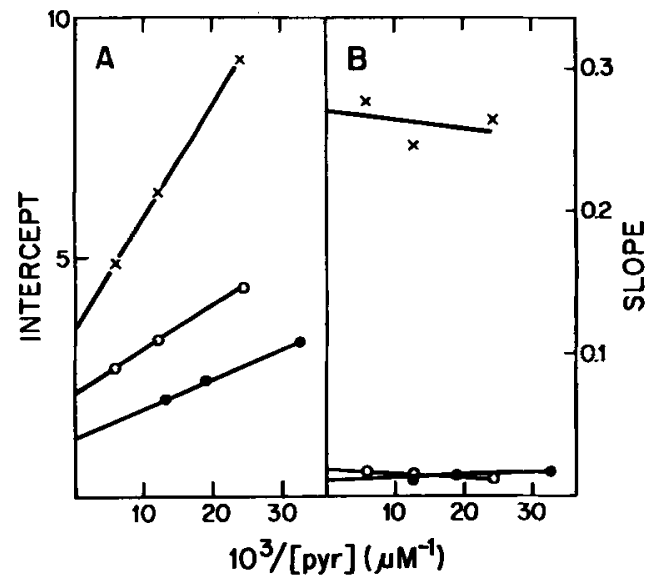

Figure 4. Plot of intercepts (Fig. $4 \mathrm{~A}$ ) and slopes (Fig. 4 B) calculated from Figs. $2 \mathrm{~A}, 2 \mathrm{~B}$ and $2 \mathrm{C}$ versus reciprocal pyruvate (second substrate) concentration. The intercepts and slopes of Figs. $4 \mathrm{~A}$ and $4 \mathrm{~B}$, obtained by linear regression, are used to calculate the MICHAELIS parameters for unmodified LDH $(-\bullet), \mathrm{C}_{6}$-modified crystals $(0-0)$ and $\mathrm{C}_{8-}$ modified crystals $(x-x)$.

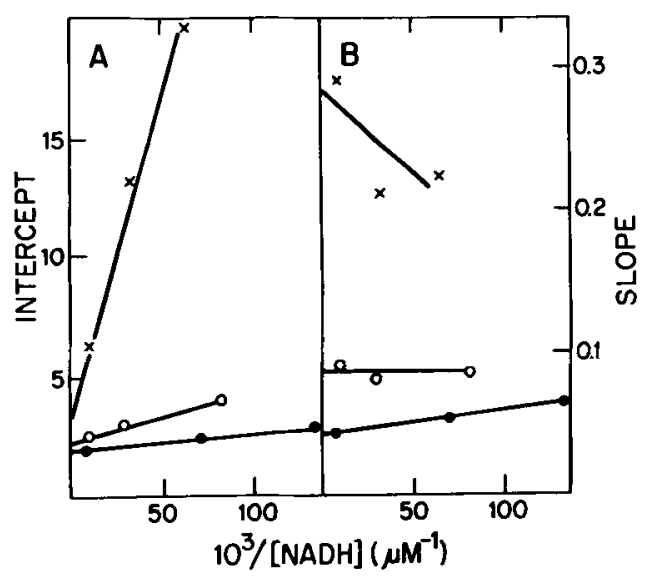

Figure 5. Plot of intercepts (Fig. $5 \mathrm{~A}$ ) and slopes (Fig. 5 B) calculated from Figs. $3 \mathrm{~A}, 3 \mathrm{~B}$ and $3 \mathrm{C}$ versus reciprocal NADH (second substrate) concentrations. The intercepts and slopes of Figs. $5 \mathrm{~A}$ and $5 \mathrm{~B}$, obtained by linear regression, are used to calculate the Michaelis parameters for unmodified LDH $(\bullet-\bullet), C_{6}$-modified crystals $(0-0)$ and $C_{8}$ modified crystals $(x-x)$. 


\section{Table II}

Kinetic parameters for pyruvate and NADH for soluble LDH and for $C_{6}$ and $C_{8}$ modified LDH crystals. The parameters were obtained as described in section 3.2

\begin{tabular}{|c|c|c|c|c|c|c|c|}
\hline \multirow[b]{3}{*}{ Preparation } & \multirow{3}{*}{$\begin{array}{l}\text { Lysine } \\
\text { modified } \\
\text { per } \\
\text { subunit }\end{array}$} & \multirow{3}{*}{$\begin{array}{c}\text { Second } \\
\text { substrate }\end{array}$} & \multicolumn{3}{|c|}{ Intercept replot } & \multirow{2}{*}{\multicolumn{2}{|c|}{$\begin{array}{l}\text { Slope replot } \\
K_{m}(\mu \mathrm{M})\end{array}$}} \\
\hline & & & $\mathrm{V}_{\max }$ & & & & \\
\hline & & & (units/mg) & pyr & NADH & pyr & NADH \\
\hline Soluble & 0 & $\begin{array}{c}\text { Pyruvate } \\
\text { NADH }\end{array}$ & $\begin{array}{l}700 \\
580\end{array}$ & 40 & 5 & 26 & 9 \\
\hline $\mathrm{C}_{6}$ (soluble) & 2 & $\begin{array}{c}\text { Pyruvate } \\
\text { NADH }\end{array}$ & $\begin{array}{l}470 \\
470\end{array}$ & 43 & 10 & 41 & 9 \\
\hline$C_{8}$ (insoluble) & 6 & $\begin{array}{c}\text { Pyruvate } \\
\text { NADH }\end{array}$ & $\begin{array}{l}300 \\
290\end{array}$ & 70 & 77 & 83 & 78 \\
\hline
\end{tabular}

reported (9). This might be due to the increased purity of the NADH preparation used in the kinetic studies.

The primary plots for the unmodified enzyme were consistent with the sequential ordered mechanism proposed for $\mathrm{LDH}(8)$

$$
\mathrm{E}+\mathrm{R} \rightleftharpoons \mathrm{ER}+\mathrm{S}_{1} \rightleftharpoons \mathrm{ERS}_{1} \rightleftharpoons \mathrm{EOS}_{2} \rightleftharpoons \mathrm{EO}+\mathrm{S}_{2} \rightleftharpoons \mathrm{E}+\mathrm{O}
$$

where $E$ is $L D H, R$ is reduced coenzyme, $O$ is oxidised coenzyme, $S_{1}$ is pyruvate and $S_{2}$ is lactate. In this mechanism, coenzyme must bind before substrate and product must dissociate before breakdown of the enzyme-coenzyme binary complex.

Primary plots for the diimidoester reacted crystals are presented in Figs. 2B and 3B for the $\mathrm{C}_{6}$-reacted crystals and in Figs, $2 \mathrm{C}$ and $3 \mathrm{C}$ for the $\mathrm{C}_{8}$-reacted crystals. None of these plots is coincident close to the abscissae and differs in this aspect from unmodified LDH. This would indicate that the reaction of diimidoester with lysine residues in LDH has altered the kinetic patterns, both in the case where the enzyme is in a dissolved form $\left(\mathrm{C}_{6}\right.$-derivative $)$ and as insoluble crystals $\left(\mathrm{C}_{8}\right.$-derivative $)$. Secondary replots of the intercepts, (Figs. 4A, 4B, 5A and 5B) however, showed good linearity allowing extrapolation of the $V_{\text {max }}$ and $K_{m}$ values for the second substrate (NADH or pyruvate respectively) from each of the replots. These $V_{\max }$ values were then used to calculate $K_{m}$ values of the first substrate (pyruvate or NADH respec- tively) from the secondary replots of the slopes. As Table II shows, good agreement was obtained in every case.

The $V_{\max }$ values decreased, relative to the unmodified enzyme, for both the $\mathrm{C}_{6}$ - and $\mathrm{C}_{8}$ derivatives. This result is surprising for the dissolved $\mathrm{C}_{6}$-derivative as it is not subject to the diffusive and steric limitations caused by the crystalline structure of the $\mathrm{C}_{8}$-derivative. However, we have evidence (see section 3.1) for the formation of soluble polymeric forms of LDH and the decreased $V_{\max }$ values of the $\mathrm{C}_{6}{ }^{-}$ derivative might thus be explained by the nonavailability of some of the active sites for reaction with substrate. The lower $V_{\max }$ values of the $\mathrm{C}_{8}$-derivative could be ascribed to additional restrictions of the access of the substrates to some of the active sites caused by the crystal structure.

The $\mathrm{K}_{\mathrm{m}}$ values for $\mathrm{NADH}$ for the $\mathrm{C}_{6}$-reacted crystals are almost unchanged compared to those for the unmodified enzyme, whereas the values for the $\mathrm{C}_{8}$-reacted crystals, which are insoluble, have increased ten-fold. On the other hand, the $K_{m}$ values for pyruvate, for both the $\mathrm{C}_{6}$ - and $\mathrm{C}_{8}$-reacted LDH, are much less dependent on the physical state. It would appear, therefore, that the change in $K_{m}$ for NADH is being caused mainly by the crystal structure, although it cannot be excluded that the increased lysine residue modification of the $\mathrm{C}_{8}$ derivative also plays a role. 


\section{DISCUSSION}

The examination of the kinetic properties of insoluble, cross-linked crystalline enzymes in dilute solution has been prompted by the realisation that the mechanism derived from $X$ ray studies, i.e. a "static" mechanism, need not necessarily be the mechanism in solution where the enzyme has more freedom to interchange among many conformations. Carboxypeptidase A has been shown to be a clear example of such differences by the work of VALLEE and his coworkers $(15,16)$, who found that the kinetics in solution were different for all substrates from the kinetics in the crystal. MADSEN and coworkers (11) with their studies on glycogen phosphorylase have found $\mathrm{K}_{\mathrm{m}}$ values to be unchanged for both substates tested whereas $V_{\max }$ values decreased at least ten-fold in the crystals compared to the free enzyme activity. TUCHSEN and OTTESEN (18), on the other hand, have examined insoluble crystals of subtilisin Carlsberg and found essentially no changes in the kinetic parameters.

In all of these studies, glutaraldehyde was used as the cross-linking reagent and initially, we also used this reagent in the work with LDH crystals. However, this treatment consistently resulted in amorphous aggregates of very low activity. We therefore turned our attention to diimidoesters, one of whose properties, namely the maintenance of the positive charge after reaction with lysine residues, might be essential for obtaining insoluble crystal preparations of high activity.

For one of the substrates, pyruvate, slight change in the $K_{m}$ value occurred upon crystallization. For the other substrate, NADH, we found substantial increases in the values of $\mathrm{K}_{\mathrm{m}}$. For both substrates, the kinetic patterns obtained with the crystals differed from those obtained with the unmodified enzyme. One conclusion which might be drawn from the increased $K_{m}$ values for the crystals is that the crystal structure is somehow preventing or restricting closure of the "loop " which has been proposed to move on the binding of coenzyme to $\mathrm{LDH}(8)$. This restriction of movement becomes apparent only in the $\mathrm{K}_{\mathrm{m}}$ value for NADH which is required to bind before pyruvate. Hence, we see only small changes in the $K_{m}$ value for pyruvate, which does not cause such extensive structural changes upon binding.

The retention of specific activity by the insoluble $\mathrm{C}_{\mathbf{8}}$-reacted crystals was much higher than that reported for carboxypeptidase $\mathrm{A}$ or for glycogen phosphorylase. This would appear to indicate that the rate limiting step in the overall reaction mechanism is unaffected by crystallization.

Our results of the effect of different diimidoesters and different concentrations of these on LDH crystals (Figs. 1A, 1B and 1C) cannot be directly compared with results for other crystalline enzymes where glutaraldehyde has been the only reagent used. The activities listed for the various modified derivatives (Figs. 1A, $1 \mathrm{~B}$ and $1 \mathrm{C}$ ) may not be true activities, since, as reported in section 3.2 , the $\mathrm{K}_{\mathrm{m}}$ value for $\mathrm{NADH}$ has increased ten-fold for the insoluble $\mathrm{C}_{8}$ modified crystals. Assuming similar $\mathrm{K}_{\mathrm{m}}$ value increases for insoluble $\mathrm{C}_{7}-$ and $\mathrm{C}_{9}-\mathrm{C}_{12}$-reacted crystals, the assay conditions described in section 2.4 will not be saturating, and the correct $\mathrm{V}_{\max }$ is not measured. However, it is still possible to infer a pattern of decreasing activity with increasing diimidoester chain length in parailel with the increasing amorphous content of the modified crystals.

The decrease of enzyme activity with increasing diimidoester chain length may also be an effect of the incorporation of hydrophobic chains on the enzyme surface. KAPMEYER and Pfleiderer (10) have noted a linear decrease of enzyme activity with increasing hydrophobic reagent incorporation, when they reacted an $\mathrm{N}$ 2,4-dinitrophenylcaproimidate with LDH. They presumed that the loss of activity was due to the hydrophobically modified surface of the protein disturbing the ordered water layer and not due to the modification of a particular lysine residue. Our experiments with methyl-3mercaptopropionimidate and its dimer also suggested that the modification of lysine residues has little effect on enzymic activity.

In summary, the results described in this paper confirm that the "static" LDH mechanism, predicted from the X-ray analysis, can be used to describe the mechanism of the dissolved enzyme. Because of the high turnover 
number of the enzyme in the direction of $\mathrm{NADH}$ oxidation diffusive effects in the crystals will influence, to a greater or smaller extent, the kinetic patterns.

\section{ACKNOWLEDGEMENTS}

The authors wish to thank Dr. I. R. RASCHED, University of Konstanz, for his critical reading of the manuscript and helpful suggestions. The entire Department of Chemistry staff and associates from the Carlsberg Research Centre who in any way aided and abetted one of us (STEPHEN BAYNE) during his stay in Copenhagen, are to be most sincerely thanked. Special thanks are due to LINDY SøNDERGAARD for the continual supply of coenzyme, to BODIL CORNELIUSSEN for performing 576 amino acid analyses and to the Royal Society for the receipt of an European Science Exchange Programme Fellowship.

\section{REFERENCES}

1. BAYNE, S. J.\& M. OTtesEN: Enzymatically active cross-linked pig heart lactate dehydrogenase crystals. Carlsberg Res. Commun. 41, 211-216 (1976)

2. Bloxham, D. P. \& D. C. Wilton: Modification of pig heart lactate dehydrogenase with methyl methanethiosulphonate to produce an enzyme with altered catalytic activity. Biochem. J. 161, 643-651 (1977)

3. Boland, M. J. \& H. Gutfreund: Pig heart lactate dehydrogenase. Binding of pyruvate and the interconversion of pyruvate-containing ternary complexes. Biochem. J. 161, 715-727 (1975)

4. Cornish-Bowden, A.: Principles of enzyme kinetics. Butterworths, London. pp. 168-193 (1976)

5. DALZIEL, K.: Initial steady state velocities in the evaluation of enzyme-coenzyme-substrate reaction mechanisms. Acta Chem. Scand. 11, 17061723 (1957)

6. Davies, G. E. \& G. R. Stark: Use of dimethyl suberimidate, a cross-linking reagent, in studying the subunit structure of oligomeric proteins. Proc. Nat. Acad. Sci. 66, 651-656 (1970)
7. Davies, G. E. \& J. G. Kaplan: Use of a diimidoester cross-linking reagent to examine the subunit structure of rabbit muscle pyruvate kinase. Can. J. Biochem. 50, 416-422 (1972)

8. Holbrook, J. J, A. Luluas, S. J. Steindel \& M. G. RossmanN: Lactate dehydrogenase. In: P. D. Boyer, ed., The Enzymes, Vol XI, pp. 191-292 (1975)

9. Kapmeyer, H., G. Pfleiderer \& W. E. TROMMER: A transition state analogue for two pyruvate metabolizing enzymes, lactate dehydrogenase and alanine dehydrogenase. Biochemistry 15, 5024-5028 (1976)

10. Kapmeyer, W. \& G. Pfleiderer: Characterisation of a highly hydrophobically modified lactate dehydrogenase. Biochim. Biophys. Acta 481, 328-339(1977)

11. Kasvinsky, P. J. \& N. B. Madsen: Activity of glycogen phosphorylase in the crystalline state. J. Biol. Chem. 251, 6852-6859(1976)

12. Laidler, K. J. \& P. S. Bunting: The chemical kinetics of enzyme action. Clarendon Press, Oxford, pp. 114-141 (1973)

13. McElvain, S. M. \& J. P. SChroeder: Orthoesters and related compounds from malono- and succinonitriles. J. Amer. Chem. Soc. 71, 40-46 (1949)

14. Reeves, W. J. \& G. M. Fumognari: An improved procedure for the preparation of crystalline lactic dehydrogenase from hog heart. J, Biol. Chem. 238, 3853-3858 (1963)

15. Spilburg, C. A., J. L. Bethune \& B. L. Vallee: The physical state dependence of carboxypeptidase $A_{\alpha}$ and $A_{\gamma}$ kinetics. Proc. Nat. Acad. Sci. 71, 3922-3926 (1974)

16. Spilburg, C. A., J. L. Bethune \& B. I. Vallee: Kinetic properties of crystalline enzymes. Carboxypeptidase A. Biochemistry 16, 1142-1150 (1977)

17. Traut, R. R., A. Bollen, T. -T. Sun, J. W. B. Hershey, J. Sundberg \& L. R. Pierce: Methyl 4mercaptobutyrimidate as a cleavable cross-linking reagent and its application to the Escherichia coli S30 ribosome. Biochemistry 12, 3266-3273 (1973)

18. TUCHSEN, E. \& M. OTTESEN: Kinetic properties of subtilisin type Carlsberg in the crystalline state. Carlsberg Res. Commun. 42, 407-420 (1977)

19. Whitaker, J. R., D. W. Yates, N. G. Bennett, J. J. Holbrook \& H. Gutfreund: The identification of intermediates in the reaction of pig heart lactate dehydrogenase with its substrates. Biochem. J. 139, 677-697 (1974) 